\title{
Belydenisvorming as kanonisering van geloofsoortuigings
}

\author{
Prof A P B Breytenbach \\ Departement Ou-Testamentiese Wetenskap \\ Universiteit van Pretoria
}

\begin{abstract}
The canonisation of religious convictions through the forming of creeds

This article deals with aspects of the process which underlies the shaping of formal creeds. Two stages are investigated: A preliminary stage in which a community of faith reacts in a polemic way to contextual questions or threats, and a secondary stage in which earlier confessions are canonised. Some of the implications of the canonisation of confessions of faith are scrutinised. The final conclusion is that the canonisation of one systematised understanding of faith runs afoul of the diversity of theologies and metaphoric language in the Old and New Testament.
\end{abstract}

\section{INLEIDING}

Die doel van hierdie artikel is tweeledig. In die eerste plek word hiermee hulde gebring aan ' $n$ kollega en vriend, J H Koekemoer, wat amptelik die einde van 'n akademiese loopbaan bereik het. Omdat 'n sistematiese teoloog gehuldig word, is dit gepas dat die artikel handel oor ' $n$ onderwerp wat van belang is vir die dogmatiek. Professor J H Koekemoer het trouens self baie nagedink oor en standpunt ingeneem oor belydenis, belydenisskrifte en belydenisvorming (vgl o a Koekemoer 1984:100-105; 1997:13211330).

In die tweede plek is hierdie artikel ook bedoel om 'n bydrae te maak tot die debat oor die vraag of die Nederduitsch Hervormde Kerk en kerke uit die Gereformeerde kerklike tradisie, tans 'n nuwe belydenisskrif nodig het. Daar kan inderdaad verskeie 
redes aangevoer word waarom dié kerk(e) dit ernstig sou moes oorweeg om in die huidige omstandighede 'n nuwe belydenisskrif die lig te laat sien. Die kerk sou in 'n nuwe belydenisskrif kon stelling inneem teenoor die heilsaanbod van die wêreld wat vanuit ' $n$ humanistiese oriëntasie tot die hart van baie lidmate spreek. Klem op die menslike vryheid en die waardigheid van die persoon klink vir moderne mense eenvoudig aantrekliker as 'n evangelie wat rekening hou met die sonde en verlorenheid van mense. Binne die politieke werklikheid waarin Suid-Afrika hom bevind sedert 1994 sou die kerk hom byvoorbeeld in 'n nuwe belydenisskrif kon verantwoord oor die feit dat die burgerlike owerheid klaarblyklik nie "die losbandigheid van die mense in bedwang" hou en "die heilige Woordbediening ... beskerm om sodoende alle afgodery en valse godsdiens teen te gaan en uit te roei" nie (NGB art 36; vgl Nederduitsch Hervormde Kerk van Afrika 1995:132 = NHKA 1995). Die openbare ansprake van die Islam, as sou dit die enigste ware godsdiens wees, is ook deel van die nuwe situasie in Suid-Afrika waarop die kerk sou kon reageer. Die kerk sou ook in 'n nuwe belydenisskrif kon standpunt inneem teenoor die voorspoedgeloof van sommige sektariese groepe wat deur moderne advertensietegnieke en die klem op die materiële voordeel wat dié groepe bied, duisende lidmate uit die sogenaamde hoofstroomkerke trek. Daar is in die geledere van hierdie hoofstroomkerke ook lidmate en teoloë wat meen dat daar in 'n nuwe belydenisskrif standpunt ingeneem moet word met betrekking tot sake soos Skrifbekouing en Skrifgesag en die uitsprake van veral Nuwe-Testamentici oor die maagdelike verwekking en liggaamlike opstanding vah Jesus Christus.

Die bedoeling van hierdie artikel is egter nie om vanuit die praktiese omstandighede waarin die kerk hom bevind, te argumenteer vir of teen 'n nuwe belydenisskrif nie, maar om die proses van belydenisvorming onder oë te neem sowel as die probleme wat dit meebring. Omdat die oortuiging wat in hierdie artikel uitgespreek word, in 'n hoë mate gevorm is deur die bestudering van die Ou Testament, sal voorbeelde ter illustrasie van 'n bepaalde standpunt ook hoofsaaklik uit die $\mathrm{Ou}$ Testament geneem word. 


\section{BELYDENISVORMING}

Met belydenisvorming word bedoel die proses waardeur die formulering van geloofsinhoud uiteindelik stol in geskrifte wat 'n bepaalde gesag het vir 'n bepaalde geloofsgemeenskap. Hierdie proses kan in twee fases verdeel word.

In die eerste plek is daar dié fase wat as die ontstaanstyd getipeer sou kon word. Die Sitz im Leben van belydenisvorming is altyd 'n gekontekstualiseerde stryd oor hoe God in sy verhouding met mense verstaan moet word. Belydenisvorming is dus uit huis uit gevestig op die stramien van dogmadiskussie. Belydenisvorming begin wanneer daar 'n alternatiewe verstaan is van wat as wesenlik beskou word in God se verhouding met mense. Hierdie alternatiewe verstaan kan 'n tradisionele wyse van verstaan wees. So het die geloofsoortuigings van die Reformatore byvoorbeeld in die tyd van die Reformasie neerslag gevind in die Nederlandse Geloofsbelydenis téénoor die alternatiewe verstaan in Rooms-Katolieke kringe. Die alternatiewe verstaan kan natuurlik ook 'n nuwe wyse van verstaan wees. Dit was die geval toe die Remonstrante, met 'n nuut geformuleerde verstaan as alternatief teenoor die Calvinistiese verstaan na vore gekom het, alhoewel teologisering oor die uitverkiesing nie nuut was nie (NHKA 1995:163). Die alternatiewe verstaan kan ook meegebring word deur nuwe vraagstelling wat twee teenoorstaande antwoorde of standpunte na vore roep. Die vraag of Jesus van Nasaret die verwagte Messias was, sou hiervan as voorbeeld kon dien. Dit is belangrik om daarop te let dat dit in hierdie eerste fase altyd gaan oor die verstaan van 'n basisteks of -tradisie soos die boeke van die Ou Testament, die Bybel of die ekumeniese simbole. Die opstellers van die Nederlandse Geloofsbelydenis beroep hulle byvoorbeeld nie net op die Ou- en Nuwe Testament nie, maar dui ook die aard van die gesag, en die grense van daardie basisteks aan, terwyl die kerklike tradisie as basisteks afgewys word (NGB art 3,6 en 7).

In die tweede plek is daar dié fase wat as die kanonisering (in die sin van toekenning van gesag deur 'n geloofsgemeenskap) van geloofsinhoud getipeer kan word. Die Nasionale Sinode van die Nederlandse Hervormde Kerk wat in 1618 en 1619 gehou is in Dordrecht, bied 'n voorbeeld van die kanonisering van geloofsoortuigings. Ná die besluite van die sinode was die proses van belydenisvorming wat neerslag gevind het in die Nederlandse Geloofsbelydenis, die Heidelbergse Kategismus en die Dordtse Leerreëls voltooi en afgesluit. Agter die kanoniseringsfase is daar altyd 'n belangegroep wat in 
omstandighede wat as 'n toestand van anomie beskryf kan word, probeer rigting gee (Deist 1995:69). Dit slaag alleen as die belangegroep binne die bepaalde gemeenskap voldoende steun geniet en oor die nodige magsmiddele soos geleerdheid of die ondersteuning van politieke maghebbers, beskik.

\section{BELYDENISVORMING AS KONTEKSTUELE TEOLOGISE- RING}

Belydenisvorming is in die eerste fase niks anders as teologisering nie. Hierdie teologisering vind neerslag in verskillende literêre vorme. Die teologisering kan neerslag vind in literêre vorme soos stellings of proposisies (die Ekumeniese simbole), in die vorm van 'n verweerskrif (die Nederlandse Geloofsbelydenis), in kategetiese onderrig (die Heidelbergse Kategismus) of in die vorm van dogmadiskussie (die Dordtse Leerreëls).

Wesenlik verskil die teologisering wat in belydenisskrifte stol, nie van ander vorme van teologisering nie. Dit geld ook vir die teologisering wat in die Ou- en Nuwe Testament opgeneem is. Daar is byvoorbeeld nie wesenlik verskil tussen die teologisering wat ingelei word met "So het die Here gesê ..." (Jer 9:23) en "Ons bely dat ..." (NGB art 3) nie. In albei gevalle word ná hierdie inleidende woorde uitsprake gemaak oor God in sy verhouding met mense, of oor die verhouding tussen mense op grond van hulle verhouding met God. Die woorde "so het die Here gesê" was in die tyd toe dit geskryf is, 'n literêre konvensie wat aan die inhoud wat volg, 'n bepaalde gesag verleen het. Die woorde "ek glo" of "ons bely dat" is ook 'n literêre konvensie wat aan die inhoud wat volg, ' $n$ bepaalde gesag gee.

Die teologisering wat in die Ou- en Nuwe Testament neerslag gevind het, verskil wel van dié in belydenisskrifte wat betref die gesag wat dit binne die geloofsgemeenskap het. Die Bybel dien, vanweë sy kanonieke status, as basisteks vir latere teologisering, onder andere ook die teologisering in die ekumeniese simbole en belydenisskrifte. Hierdie latere teologisering kan begrond word met verwysing na die basisteks (naamlik die Ou en Nuwe Testament) of na 'n tradisie van verstaan van daardie basisteks. Waar die basisteks of ' $n$ bestaande verstaanstradisie nie voldoende grond verskaf vir die latere teologisering nie, kan dit op 'n skolastiese wyse onderbou word. Artikel 19 van die Nederlandse Geloofsbelydenis is hiervan 'n goeie voorbeeld. Omdat die Ou- en Nuwe 
Testament in Protestantse kringe die status van 'n afgeslote kanon gehad het, kon die teologisering wat byvoorbeeld in die Nederlandse Geloofsbelydenis neerslag gevind het, nie met dieselfde gesag beklee word nie. Dit was trouens ook nie die bedoeling om in die eerste fase van belydenisvorming vir hierdie verweerskrif gesag op te eis nie. Dit het eers gebeur in die tweede fase as gevolg van sinodebesluite waarvan die finale dié by Dordrecht was.

Die teologisering wat in die eerste fase van belydenisvorming neerslag vind, is altyd kontekstueel. Dit probeer antwoord gee op die eietydse vraagstelling. Die alternatiewe verstaan van die Rooms-Katolieke Kerk, die Wederdopers en die Remonstrante het die skopus en inhoud van die teologisering by die belydenisvorming in Reformatoriese kringe beslissend bepaal. So byvoorbeeld is artikel 36 van die Nederlandse Geloofsbelydenis niks anders nie as 'n antwoord op die beskuldiging dat die Calviniste die burgerlike owerheid omver wou werp. Teen hierdie beskuldiging word duidelik standpunt ingeneem in die voorrede tot die Nederlandse Geloofsbelydenis (NHKA 1995:111):

Daar word gesê dat ons ongehoorsame rebelle is wat slegs ten doel het om die staatkundige orde omver te werp en verwarring en chaos in die wêreld aan te rig. Verder, dat ons nie alleen onder $u$ heerskappy en gesag probeer uitkom nie, maar dat ons u ook van u troon wil stoot. Ons word dus aangekla van misdade wat nie strook met ons belydenis nie, nie met die lewe van 'n Christen nie en selfs nie met mens wees in die algemeen nie.

Die stelling kan gemaak word dat indien die Protestante nie beskuldig is van opstand teen die owerheid nie, artikel 36 na alle waarskynlikheid nie deel sou wees van die belydenis nie. Artikel 36 word begrond met Romeine 13:2 en I Timotheus 2:2 wat op hulle beurt weer antwoorde gegee het op vrae in die vroeë kerk.

Om in die tyd van ontstaan sin te maak, móét elke vorm van teologisering trouens kontekstueel wees. Daar is in alle sinvolle spreke oor God in sy verhouding met mense, 'n polemiese element. Wie ernstig teologiseer, raak nie maar net 'n klomp algemene waarhede kwyt nie, maar tree in debat met 'n bestaande standpunt, oortuiging of toestand. 
So profileer die omstandighede waarin die spreke oor God plaasvind, die teologisering, ook en juis in die geval van belydenisvorming.

\section{BELYDENISVORMING AS GEKANONISEERDE VERSTAAN: ENKELE PROBLEME}

Terwyl die kontekstuele gerigtheid in die eerste fase van belydenisvorming daaraan ' $n$ egtheid gee en dit sinvol maak, kan dieselfde nie van die kanoniseringsfase gesê word nie. Die konteks waarbinne kanonisering plaasvind is, soos reeds aangedui, 'n situasie van dogmadiskussie. Terwyl die eerste fase van belydenisvorming meestal as stellingname en verweer gerig is teen 'n "buitegroep" soos die Rooms-Katolieke Kerk of die Anabaptiste (gesien vanuit die Protestants-Calvinistiese hoek), is kanonisering meer dikwels gerig teen 'n binnegroep, dit wil sê teen 'n alternatiewe verstaan in eie geledere. Die kanonisering van belydenisskrifte tydens die sinode te Dordrecht is hiervan 'n goeie voorbeeld. Die besluite in die stryd rondom Arius is ook 'n voorbeeld hiervan. 'Die gevolg van kanonisering is dan ook meestal 'n suiweringsproses waardeur geloofsgenote wat die basisteks anders verstaan, uit die groep geëkskommunikeer word.

Omdat dit die versweë of uitgesproke doel van kanonisering is om die debat oor 'n saak af te sluit, kom dit altyd met die pretensie dat dit die waarheid gesaghebbend "saamvat" en wel op so 'n wyse dat geen debat meer daarna behoort plaas te vind nie. So 'n samevatting of selfs ook sistematisering van die waarhede van die Skrif is natuurlik 'n verskynsel wat in die na-Bybelse tyd ontwikkel het.

Die Ou Testament bied oorvloedige getuienis daarvan dat uiteenlopende en selfs teenoorstaande perspektiewe op die verhouding God en mens gewoon gehandhaaf is in dieselfde versameling heilige geskrifte (Breytenbach 1997:1171-1180). So byvoorbeeld word die boek Obadja met sy veroordeling van alle vyande van Juda gevolg deur die boek Jona waarin die liefde van JHWH vir die aartsvyande van Israel een van die hoofmotiewe is. In dieselfde versameling (naamlik die Ou Testament) staan 'n boek soos Spreuke as tipiese wysheidsgeskrif wat die sogenaamde vergeldingsdogma steun, én

\footnotetext{
$1 \mathrm{Vgl}$ in hierdie verband McGrath (1990:41): "Where the Donatist schism (313-16) had merely obliged Constantine to determine which of two rival social groupings could legitimately claim to be the true church, the Arian controversy obliged him to determine which of two rival doctrines was the teaching of the catholic church. With the imperial resolution of the Arian crisis, 'doctrine' rapidly assumed the character of legally sanctioned ideology - a concept perhaps accurately designated 'dogma'."
} 
boeke soos Job en Prediker wat vernietigende kritiek lewer op dieselfde vergeldingsdogma. Dit geld ook vir die boeke 1 en 2 Kronieke wat die kultus en koningskap in Jerusalem positief beoordeel teenoor die negatiewe beoordeling van 1 en 2 Konings en veral die boek Jeremia.

In die geval van die boek Miga is teenoorstaande en uitsluitende inhoud selfs in dieselfde boek opgeneem (Van der Woude 1976:10). Wat meer is, die opponente van die profeet Miga beroep hulle op die profesieë van die profeet Jesaja (Van der Woude 1976:127-141). Van der Woude vat die saak soos volg saam (1976:131):

Is Micha 4:1-5 inderdaad door de opponenten van de profeet gesproken, dan vormen deze woorden een zeldzaam voorbeeld van het misbruik van 'canonieke' profetie ten dienste van eigen ideologie. Daaruit mogen blijken dat het verschil tussen 'ware' en 'valse' profetie nie gelegen is in een verschillende 'objective' waarheid, maar in een ideologisch gebruik van de waarheid met voorbijzien van het feit dat 'werkelijke waarheid' haar eigen tijd en uur heeft.

Dieselfde geld ook vir die Nuwe Testament. In dié verband sê McGrath (1990:3) byvoorbeeld: "Conflict is inherent within the tradition concerning Jesus: that tradition does not merely generate conflict, but transmits it as an essential constituent element."

Hierdie verskille het naas verskillende ideologiese perspektiewe soms ook te doen met verskillende omstandighede van die outeurs. Die spanning wat hierdie uiteenlopende en teenoorstaande perspektiewe skep, is egter wesenlik deel van dieselfde gekanoniseerde heilige boeke waarop alle.grondige teologisering behoort te berus. Hierdie inherente spanning lei onvermydelik tot die gevolgtrekking dat die waarheid van die Skrif nie enkelvoudig is nie en dat die waarheid, soos Van der Woude sê,, gebonde is aan plek en tyd.

Om die waarheid dus gesaghebbend saam te vat, is nie net 'n na-Bybelse ontwikkeling in die teologie nie; dit is, in die lig van die inhoud van dieselfde Bybel, eintlik onmoontlik. Dit kan alleen geskied deur 'n selektiewe lees van die Bybel. Die feit dat die gekanoniseerde belydenisskrifte daarna uitleg verg, bevestig maar net dat ook die 
waarheid van die eerste fase van belydenisvorming net soos die teologisering in die Bybel self, gebonde was aan tyd en plek.

Die sistematisering van geloofsinhoud in belydenisskrifte en die kanonisering daarvan, word moontlik gemaak en feitlik altyd gedra deur 'n vorm van sisteemdenke. Een van die vertrekpunte in sisteemdenke is dat die waarheid in proposisies saamgevat kan word en dat die waarheid enkelvoudig is. ${ }^{2}$ Hier skuil 'n wesenlike gevaar: As teologiese waarheid in 'n sisteem ingepas kan word, gee dit beheer oor die waarheid en in 'n sekere sin ook oor God omdat sy handelinge in 'n hoë mate voorspelbaar word vanuit die sisteem. Verder word die waarheid en ook die God van dié waarheid stilswyend opgeeïs deur dié wat meen dat hulle die waarheid ken en beheer. Die boek Job bied 'n uitstekende voorbeeld van sisteemdenke waar Job se vriende meen dat hulle vanuit hulle (vergeldings)dogma Job se probleem en God se optrede kan verklaar.

Sisteemdenke en die illusie dat die waarheid enkelvoudig en beheerbaar is, staan egter dwars op die grein van die Bybel. Die Ou- en Nuwe Testament breek magstrukture en beheer af, veral as dit die soewereiniteit van God aantas. Die God van die Bybel is absoluut soewerein. Hy is dikwels jammer oor kwaad wat Hy mense wou aandoen (bv Jona 4:2). Hy kan selfs ook jammer wees oor iets wat aanvanklik goed was (Gen 1:32 en 6:5v; 1 Sam 9:15v en 15:35; Jer 18:7-10; vgl Loader 1999:326-338). Psalm 73 bied 'n goeie voorbeeld daarvan dat 'n (dogmaties) korrekte "belydenis" oor God, waarop die psalmdigter sy lewe en hoop gebou het (naamlik "God is vir Israel baie goed, vir dié wat rein van hart is"), nie "waar" is nie. Die ontdekking van die psalmdigter dat hy, deur sy verwagting wat op hierdie "belydenis" gebou is, God eintlik tot sy eie voordeel wou manipuleer (vs 13v), bring hom tot die erkenning dat dit dwaas is om só oor God te dink (vs 2lv). Die (verlossende) ontnugtering van die psalmdigter is dat hy besef dat God ook, anders as wat die belydenis sê, nié goed hoef te wees vir dié wat hulleself rein hou nie. Dit gaan dus in die eerste plek nie daaroor dat God goed is vir dié wat hulle rein hou nie, maar dat die hoogste goed is om net met Hom in 'n verhouding te mag staan(vs 28).

Die God van die Bybel pas nie in enige sisteem nie. Reeds in die Ou Testament word in 'n "belydenis" oor Hom teenstellende uitsprake gemaak. As die vertelling in

\footnotetext{
$2 \mathrm{Vgl}$ Van Aarde (1999:11-27) vir 'n bespreking van die probleme rondom 'n modernistiese verstaan van "waarheid".
} 
Eksodus uitloop op die vraag wat JHWH gaan doen met Israel wat binne veertig dae die verbond met Hom verbreek het (Eks 32:1-30), dan word dit uiteindelik 'n vraag van Moses na wat ons (by gebrek aan 'n beter term) sou kon noem die "wese" van JHWJ ${ }^{3}$. Die antwoord wat hierop gegee word, bevat ' $n$ inherente teëspraak (Eks 34:6v):

JHWH, JHWH is 'n barmhartige en genadige God, geduldig en vol liefde en trou; wat sy liefde aan duisende (geslagte) bewys; wat skuld, opstand en sonde vergewe maar wat beslis nie (skuldiges) ongestraf laat nie; wat kinders en kleinkinders, agterkleinkinders en agteragterkleinkinders tot verantwoording roep vir die sonde van die voorvaders. ${ }^{4}$

Hierdie inherente teëspraak bevestig onder andere maar net dat JHWH soewerein is. Dit word trouens in die voorafgaande vertelling in soveel woorde gesê as daar staan: "Ek sal genadig wees oor wie Ek genadig wil wees, en My ontferm oor wie Ek My wil ontferm" (Eks 33:19).

Die waarheid oor God, wat gelowiges in mensewoorde probeer uitdruk, is soos reeds aangedui, nie tydloos nie. Van der Woude vat die saak baie goed saam wanneer hy oor Miga 4:1-5:14 die volgende sê (1976:190v):

Ook die heilswaarheid is als werkelijke, effectieve, heilbrengende waarheid aan uur en tijd gebonden. Daarom kunnen pseudo-profeten woorden van Schriftprofeten misbruiken, maar kunne pseudo-profetische teksten ook tot canonieke Schrift worden .... Beschouwde men God in die tijd vóór de ballingschap te gemakkelijk als garant van het heil, in en na het exil twijfelde

\footnotetext{
3 Vgl Eks 33:18. Die Hebreeuse teks lees הראני :א את־כברך; die Septuaginta gee dit weer met

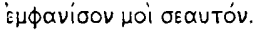

4 Die essensie van hierdie belydenis (naamlik die eerste deel) is dikwels die beroepsgrond vir gelowiges wat pleit om vergifnis; vgl Num 14:18; Neh 9:17; Ps 86:15; 103:8; 145:8 en Joël 2:13. Vgl ook Loader (1999:330-332).
} 


\section{Belydenisvorming as kanonisering van geloofsoortuigings}

men aan Hem als schepper van het heil (Mal 3:14). In laatstgenoemde situatie moet de ongeconditioneerde heilsprediking en het sola gratia volop klinken. Omgekeerd kan het nodig zijn begrippen als verbond en verkiezing te verzwijgen om niet verder voet te geven aan zelfgenoegzaamheid .... Daarmee zijn de heilsbeloften als zodanig echter niet ontkend. Wel echter dat een eenmaal aangeboden getuigenis - hoe dogmatisch onaanvechtbaar ook als richtingwijzend woord van God kan worden gebruikt, zonder dat daarbij tijd en gelegenheid in het geding worden gebracht.

Getuienis oor God (hoe dogmaties onaanvegbaar ook al) kan nie as rigtinggewende woord van God gebruik word sonder om die tyd en omstandighede waarin dit uitgespreek is, baie deeglik in berekening te bring nie. Dit geld nie net vir die woorde van die kanonieke Skrif nie; dit geld veral ook vir die teologisering daaroor in nuwe omstandighede - en dan juis dié teologisering wat uiteindelik in belydenisskrifte stol. Die kanonisering van belydenisskrifte impliseer te gemaklik dat die ewige waarhede (en daarmee word meestal bedoel tydlose waarhede) van die Skrif daarin volkome saamgevat is.

Die feit dat alle spreke oor God metafories of analogies van aard is (vgl Van Aarde 1995:40-48), mak dit in beginsel ook onmoontlik om 'n besondere verstaan van die Skrif as ewig geldende waarheid te kanoniseer. Elke tyd bring met sy eie omstandighede mee dat dié metafore (of analogiese taal) in teologisering gekies word wat op die vrae van daardie tyd en in daardie kultuur antwoord moet gee. Wanneer Israel tydens die Siro-Efraimitiese oorlog (734-732 vC) eers in opstand kom teen, dan hulp soek by, en later grondgebied moet afstaan aan die Assiriese koning, gebruik die profeet Hosea die beelde van 'n etterende sweer, beentering en 'n leeu om dit duidelik te maak dat JHWH en nie die Assiriese koning nie, hulle in die noute gebring het (Hos 5:12-15). Om in ánder omstandighede en in 'n ander kultuur te sê "God is 'n etterende sweer en beentering vir sy volk", kan so skokkend wees dat dit negatief kommunikeer. Die juridiese en kultiese metafore wat op voetspoor van die Bybel in die belydenisskrifte gebruik word om oor die dood van Jesus te praat (vgl NGB art 2; HK Sondag 15) kommunikeer ook soms negatief in die moderne tyd. 
Daar is dus iets te sê vir die "ontmitologisering " van die Skrif in ons eie tyd, vir die deurvra na die "saak" waaroor dit in die Skrif gaan. Wie dit doen moet egter baie goed begryp dat óns onder woorde bring van wat die Skrif oor God sê, óók analogiese taal is. Ons het dus nooit die waarheid oor God nie, maar word daarmee gekonfronteer en "ontdek" dit, juis in metafories-analoë spreke oor God.

'n Laaste saak wat kortliks aandag vra, is die feit dat die verstaan van 'n basisteks bewustelik of onbewustelik berus op eksegeties-hermeneutiese vertrekpunte. Die NuweTestamentiese skrywers het, in aansluiting by die gangbare Joodse uitlegmetodes van hulle tyd, die Ou Testament geïnterpreteer vanuit die vertrekpunt dat die boeke van die Ou Verbond primêr beloftes bevat wat in die gebeure rondom Jesus van Nasaret en die ontstaan van die kerk vervul is. In hulle interpretasie van die Ou Testament is daar ruim gebruik gemaak van die sogenaamde pesher ${ }^{5}$ asook tipologiese (vgl Rom 5:12-21; 1 Kor 10:1-13; 15:21-22; Heb 7:1-17; 1 Pet 3:21, ens) en selfs allegoriese (1 Kor 9:8-10; Gal 3:16; 4:24; 1 Tim 5:18) wyses van uitleg. Die basiese veronderstelling by hierdie soort interpretasies is dat daar ' $n$ dieper, verborge betekenis in die woorde van die Ou Testament skuil wat slegs toeganklik is vir diegene wat glo (2 Kor 3:14-17; vgl Ef 5:32 waar, anders as wat die Rooms-Katolieke en Protestantse tradisies dit interpreteer, die woorde

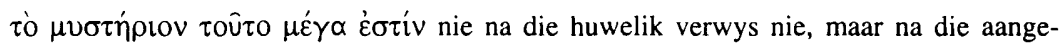
haalde Skrifwoord). Die gemeenskaplike by al hierdie wyses van uitleg is dat dit telkens 'n selektiewe lesing is wat die woord of sinsnede buite die verband waarin dit staan, interpreteer.

Alhoewel die Reformatore soos Luther radikaal weg beweeg het van die allegoriese uitleg, het hulle die Ou Testament steeds gelees vanuit die vertrekpunt dat daarin verwys word na die lewe en werk van Jesus Christus. Die belofte-vervullingskema het dus steeds as hermeneutiese sleutel gedien vir die verstaan van die Ou Testament (vgl in dié verband NGB art 17 en 18). Hierdie wyse van uitleg kan egter alleen gehandhaaf word as die veronderstelling van ' $n$ dieper betekenis, 'n selektiewe lees van die Ou Testament en die aanhaal van woorde buite die verband waarin hulle staan, steeds geld. 'n Klassieke voorbeeld hiervan is die sogenaamde "moederbelofte" in Genesis 3:15 (vgl

\footnotetext{
${ }^{5} \mathrm{Vgl} \mathrm{Hay}(1976: 444)$ "... pesher ... where the text forms of OT passages are selected or altered to bring out the commentator's interpretation ...."
} 
NGB art 17). Teenoor die interpretasie dat hierdie ' $n$ verwysing is na Christus se oorwinning oor die bose. staan die volgende: Die feit dat dieselfde werkwoord (ףש) gebruik word om die aanval van die vrou en die slang se nageslag op mekaar te beskryf, dui reeds daarop dat hier nie van oorwinning van die een oor die ander nie, maar van voortdurende vyandskap sprake is. Dit word bevestig deur die feit dat die straf wat oor die vrou en die mens aangekondig word (Gen 3:16-19), nie dieper betekenisse inhou nie, maar 'n verklaring bied vir gewone ervarings wat die alledaagse lewens van mans en vroue moeilik maak (vgl in dié verband bv ook Van Selms 1967:55-58). Indien die hermeneutiese vertrekpunt soos tans is dat woorde se betekenis bepaal word deur die verband waarin hulle staan, kan die uitleg van Genesis 3:15 as 'n verwysing na die oorwinning van Christus oor die bose, dus nie meer gehandhaaf word nie. Die kanonisering van ' $n$ belydenisskrif yk die verstaan van bepaalde gedeeltes van die Bybel en legitimeer eksegeties-hermeneutiese vertrekpunte wat eie is aan die bepaalde tyd, maar later nie meer aanvaar word nie (vgl bv Paulus se gebruik van allegoriese uitleg en Luther se kritiek op allegorese en allegoriese uitleg).

In die lig van die voorafgaande kan gestel word dat die tweede fase van belydenisvorming dus baie meer probleme oplewer as wat dit oplos. Die standpunt wat hier gestel word, bring egter ook vrae wat met mekaar saamhang, na vore: Beteken die kritiek wat gelewer word op die sistematisering en kanonisering van geloofsinhoud,

- dat alles maar gerelativeer word en dat elkeen kan glo wat hy of sy wil, en

- dat die eerste fase van belydenisvorming daarmee ook onder verdenking kom?

\section{SLOTBESKOUING}

Die kritiese wetenskap het sedert die Aufklärung 'n radikale invloed gehad op die verstaan van die Bybel. Dat dit in die Ou- en Nuwe Testament gaan oor ('n) God wat met mense in verhouding tree en ook daardie verhouding in stand hou, word egter ook deur hiperkritiese wetenskaplikes toegegee. Of 'n mens hierdie "boodskap" oor 'n transendente God aanvaar as die sin van jou lewe, is wel 'n saak van geloof.

Hierdie geloof berus nie op die sekerheid wat 'n sluitende sisteem bied nie. Geloof is nie ' $n$ religieuse securitas nie, maar die certitudo van 'n diepe afhanklikheid 
van 'n onsienlike God. Dit is 'n vaste oortuiging oor dit wat nie gesien nie, maar gehoop word. Kritiek op die kanonisering van geloofsoortuigings beteken nie dat alles gerelativeer word nie. Die Bybel met sy uiteenlopende en selfs teenoorstaande perspektiewe op die verhouding tussen God en mens, bly binne die Protestantse tradisie die enigste basisteks vir teologisering en vir geloof in ons eie tyd. Juis die diversiteit van hierdie basisteks profileer die geloof in God: Geloof is nie 'n gearriveerdheid nie maar 'n konstante soek én vind. Soos Luther gesê het: Dis waar, ons bly bedelaars voor God. Geloof is minder kennis en meer vertroue. Dit is nie 'n skolasties verklaring van alles nie, maar die erkenning dat ons baie nié weet nie. Hierdie nie-weet maak ruimte vir die verwondering as 'n wesenlike element van geloof. Dieselfde pleidooi vir ' $n$ geloof wat in verwondering kan swyg, word al in die boek Job gelewer: Die vriende van Job wat alles kon verklaar in netjiese teologiese taal, word afgewys en Job, die kritiese opstandeling wat in verwondering tot swye gebring word, word gevindikeer (Job 47:7v).

'n Egte geloof sál uitdrukking vind in woorde. 'n Belydenis (mondeling of skriftelik) word nie beplan nie; dit word gebore wanneer die geloof eg en die omstandighede reg is. Wie geloof bely met 'n nuwe verwoording, doen dit met die wete dat nie ons regte verstaan of onder woorde bring, die verhouding met die lewende God konstitueer nie, maar sy genade in Jesus Christus. Wie geloof bely, doen dit ook met die wete dat die gemeenskap van gelowiges van alle eeue op 'n manier saam praat oor die onbegryplike en onbeskryflike God. Binne die gemeenskap van gelowiges word die twyfelaar en die een wat God wil verloën, immers staande gehou (Ps 73:15).

\section{Literatuurverwysings}

Breytenbach, A P B 1997. Meesternarratiewe, kontranarratiewe en kanonisering: 'n Perspektief op sommige profetiese geskrifte. HTS 53(4), 1161-1186.

Deist, F E 1995. Canonical literature: Some ideology-critical observations, in Nel, P J \& Van den Berg, D J (eds), Concepts of textuality and religious texts. Bloemfontein: UOVS. (Acta Academica, Supplementum 1.)

Hay, D 1976. s v Interpretation, History of, in Crim, K et al (eds), The interpreter's dictionary of the Bible: Supplementary Volume. Nashville: Abingdon. 
Koekemoer, J H 1984. Die verbondstruktuur in die belydenisskrifte en formuliere. HTS 49, $100-105$.

- 1997. Enkele motiewe vir 'n eietydse verstaan van die belydenisskrifte. HTS 53, 1321-1330.

Loader, J A 1999. Gottes Umkehr und prophetische Absurdität: Zum umgekehrten Bekenntnis in Jona 4:2-3. OTE 12(2), 326-338.

McGrath, A E 1990. The genesis of doctrine: A study in the foundation of doctrinal criticism. Grand Rapids: W B Eerdmans.

Nederduitsch Hervormde Kerk van Afrika. Diensboek 1995. Pretoria: Kital.

Van Aarde, A G 1995. Kerk en teologie op pad na die derde millenium: Gedagtes oor die kontekstualisering van die dialektiese teologie in 'n plurale samelewing. HTS 51, 39-64.

- 1999. Wat is waarheid? 'n Teologiese antwoord van 'n Bybelwetenskaplike, in $20^{\circ}$ eeu Hervormde Teologie. Pretoria: Promedia.

Van der Woude, A 1976. Micha. Nijkerk: Callenbach. (POT.)

Van Selms, A 1967. Genesis, deel I. Nijkerk: Callenbach. 